\title{
The Islamic Vehicle Financing Market in Malaysia: Identification of Factors Influencing Price Sensitivity
}

\author{
Jan Werner ${ }^{1}$
}

\begin{abstract}
In recent years, Islamic finance has gained increasing attention by financial corporations in countries that are marked by a considerable Muslim population. In conjunction, Malaysia's Islamic vehicle finance market has experienced a period of rapid growth and is now maturely coexisting besides conventional vehicle financing. Nonetheless, corporations question in how far it is viable to charge a price premium for Islamic products to compensate the additional effort required. As little research is in existence about the price sensitivity of customers towards these product offerings, this study aims to examine factors that influence the price sensitivity in the Islamic vehicle financing market. Potential influencing factors were identified in literature covering Islamic banking and a model is subsequently tested by an experimental survey that was distributed within Malaysia. The study concludes that not only the belongingness to Islam is influential, but also the way of practicing the religion and the knowledge about Islamic finance. The awareness of the specific Islamic vehicle financing product makes customers less price sensitive as well as the marital status. The results of this study are beneficial to corporation who perform pricing decisions according to specific customer segments.
\end{abstract}

\section{Introduction}

Islamic finance, the alternative to the conventional banking practice that is following the teachings of Islam, has recently gained considerable attention in the banking industry and wider coverage in the media worldwide. Especially in Malaysia, the field has experienced a period of rapid growth over the past two decades, spanning a broad scope that reaches all aspects of the financial industry, including investments, financing and trading (EY MENA, 2015). Islamic finance differs from conventional finance in aspects such as the prohibition of interest, gambling or uncertainty, wherefore corporations in the finance sector of Muslim-majority countries are required to develop constant innovations in alternative offerings. Worldwide, more than US\$ 1.8 trillion assets are managed according to the principles of the Islamic holy book (Hereafter: Qur'an) and Malaysia is with US\$230.3 billion assets among the forefront of size and innovation in the field (International Monetary Fund, 2017). Further, the country is considered as a flourishing market that stipulates the most developed, as well as most important Islamic finance environment worldwide (Thomson Reuters Zawya, 2017). In the beginning of the 1980s, the first Islamic banks were founded here and since then, the government and the Malaysian Central Bank (Hereafter: Bank Negara) are actively supporting the sector with advantageous policies and educational campaigns. Thus, the public awareness of Islamic finance is high in the overall population among both Muslims and non-Muslims, and since Islamic products are often priced equally to the conventional counterpart, they enjoy acceptance in both religious groups. However, the offering of an Islamic finance product carries considerable efforts and investment costs to corporations, wherefore it is in wide debate whether the price is required to be on par to a conventional product or whether a premium on such offerings can be charged.

\footnotetext{
1 Jan Werner received a bachelor degree in International Business (Specialization: Emerging Markets) in 2017 and worked in Malaysia, Hong Kong \& Germany afterwards. He will start his Master in Finance \& Investments in 2018. Contact: janw.hamburg@gmail.com
}

The Islamic Vehicle Financing Market in Malaysia: Identification of Factors Influencing Price Sensitivity 
This question is of high relevance to the vehicle financing sector, where $42.32 \%$ of the financing volume are financed according the principles of Islam and the eleven largest banks in the market have incorporated Islamic finance into their product portfolio (Bank Negara Malaysia, 2016). Further, the significance of a sound pricing decision in relation to conventional offerings exists because the country is worldwide leading in the development of the dual banking system, consisting of an established conventional as well as an Islamic sector. So far, several studies have investigated the selection factors for Islamic banks over conventional banks in general, but little research is published about price sensitivity of Islamic finance product offerings. Therefore, Malaysia stipulates an inviting research environment to investigate this question, with both banking industries well developed in duality and a considerable amount of related research readily available.

Ultimately, this thesis aims to extend the existing research scope through the identification of factors that influence the price sensitivity in the Islamic vehicle-financing environment. For this, the variables that have been identified in previous studies as significant Islamic bank selection factors are tested to investigate their significance for the price sensitivity. An experimental survey was designed to construct a price sensitivity index that makes the assessment of influencing factors by means of a regression feasible. To identify the factors influencing the price sensitivity in the Islamic vehicle financing environment, the study commences by giving a background introduction to the general principles of Islamic finance, before the Islamic vehicle financing sector in Malaysia is elaborated. Next, a review of linked and relevant literature is presented and subsequently hypotheses a formulated. Afterwards, the methodology of the conducted research is outlined before results are presented. Finally, implications are discussed, limitations shown and ultimately, a conclusion is provided.

\section{Literature Review}

\subsection{Background on Vehicle Islamic Finance}

According to Moghul (2006), the concept of Islamic finance originated 1450 years ago with the teaching of the Muslim prophet Mohammed and the establishment of the Shariah law, which is the network of rules that sways over all aspects of Muslim life and thereby also covers all economic transactions. The verses that are written in the Qur'an and the teachings by the prophet Mohamed rule how economic transactions are to be conducted to be in compliance with the Shariah law. Generally, money in Islam is viewed without intrinsic value and only works as a method of exchange, however not as a mean for the generation of profit alone. Foremost, Islamic finance is marked by five major guiding principles that differentiate it from conventional finance: 1) Prohibition of interest rates, 2) Prohibition of uncertainty, 3) Prohibition of gambling, 4) Prohibition of sin dealings, 5) Transactions that all need to be asset based. As these principles need to be fulfilled in order to conduct financial transactions in a Shariah-compliant manner, conventional products like classic straight-line loans (which involve interest) or insurances (which involve uncertainty) are not permissible in Islam, hence modified structures were developed (Iqbal \& Mirakhor, 2011). Importantly, despite the name of Islamic finance, access is not restricted to people of Muslim faith alone, but should be seen as open to the whole population, while not standing in conflict with any religious teachings (Ramli, 2017).

With continuing growth of the significance of Islamic finance, several Shariah-compliant financing concepts arose that enable a close duplication of conventional offerings, and four structures are standing out. According to Zubairi (2011), the most significant concept in Islamic finance is the Mudarabah contract, 
with which classical banking transactions can be conducted. Instead of charging interest rates and earning profits on the interest rate differential, an Islamic bank invests collected deposits in real assets and entrepreneurship, with the generated profit being shared afterwards according to a pre-specified profit rate between bank and depositors. This structure is the foundation of Islamic finance and has been practiced on a small scale since the living of prophet Mohamed, however grew only recently into proficiency. A similar development can be observed in the so-called Musharaka contract, which is a partnership between investor and bank, where the proceedings of a joint investment are shared according to a predefined profit rate. This concept finds its application in investing on margins, however without any interest rates being involved. It differs from the aforementioned concept of Mudarabah, as in Mudarabah the bank acts as an intermediary and is solely responsible for the investment, whereas in Musharaka a joint investment is executed.

The third concept of greater importance is the Al-Bai contract, which limits uncertainty but otherwise replicates the structure of a conventional sales contract. The fourth concept of significance is the Ijarah contract, replicating a lease or rental contract that transfers the usufruct of a real asset to a second party for a specified period in return for a monetary compensation (Bank Negara Malaysia, 2014). The initial definition of Ijarah was closely related to an operational lease contract where a lessor transfers the usufruct of an asset to a lessee for a specified period and after expiration regains the asset. But in the recent 20 years, this product structure had undergone a rapid transformation phase in Malaysia, with the Ijarah structure being combined with other Islamic contracts to also enable financial leases and classic 'Hire Purchase' loans. The Islamic replication of the 'Hire Purchase' contract is a combination of an Ijarah contract and an Al-Bai contract, called 'Al-Ijarah Thumma Al-Bai' (Hereafter: AITAB) and enjoys wide acceptance in Malaysia's vehicle financing market since its inception in the 1980s (Bank Islam Malaysia Berhad, n.d.).

Usually, vehicle financing in Malaysia is conducted under a 'Hire Purchase' contract, where a customer first hires a car for a set tenure from the bank and subsequently gains ownership with the last instalment. Instalments are paid with an added-on interest rate and late payment is penalized through an interestbased late payment fee. However, this product is not permissible under the Shariah law, wherefore the AITAB structure is widely used in the Islamic industry (Abdullah \& Dr. Dusuki, 2014). As this product is a combination of two contracts (Ijarah and $A /$-Bai), documentation differs for the end-customer, who is required to sign two separate contracts rather than one under conventional financing. Since no interest can be charged, a profit rate that often mirrors the interest rate is imposed and late payment charges can differ because the bank is not allowed to charge late payment interest. Nevertheless, to stay competitive with the conventional sector, the Bank Negara allows the commonly practiced charge of $8 \%$ if $7 \%$ are passed on to charity (Ramli, 2017). Consequently, no noticeable difference arises to the end-customer and the close similarity between Islamic finance under AITAB and conventional finance under 'Hire Purchase' in Malaysia allows for a viable comparison to investigate the price sensitivity for Islamic finance offerings.

\subsection{The Malaysian Islamic Vehicle Finance Market}

The product structure of AITAB originates in Malaysia and was first introduced by Bank Islam Malaysia Berhad at the end of the 1980s, since then it is constantly showing high growth rates and is nowadays among the most popular Islamic financing products (Bank Islam Malaysia Berhad, n.d.). 16.2\% of the Islamic finance volume in Malaysia 2016 falls under AITAB (Figure 1) and the eleven largest retail banks in Malaysia all maintain an AITAB offering within their product portfolio. 


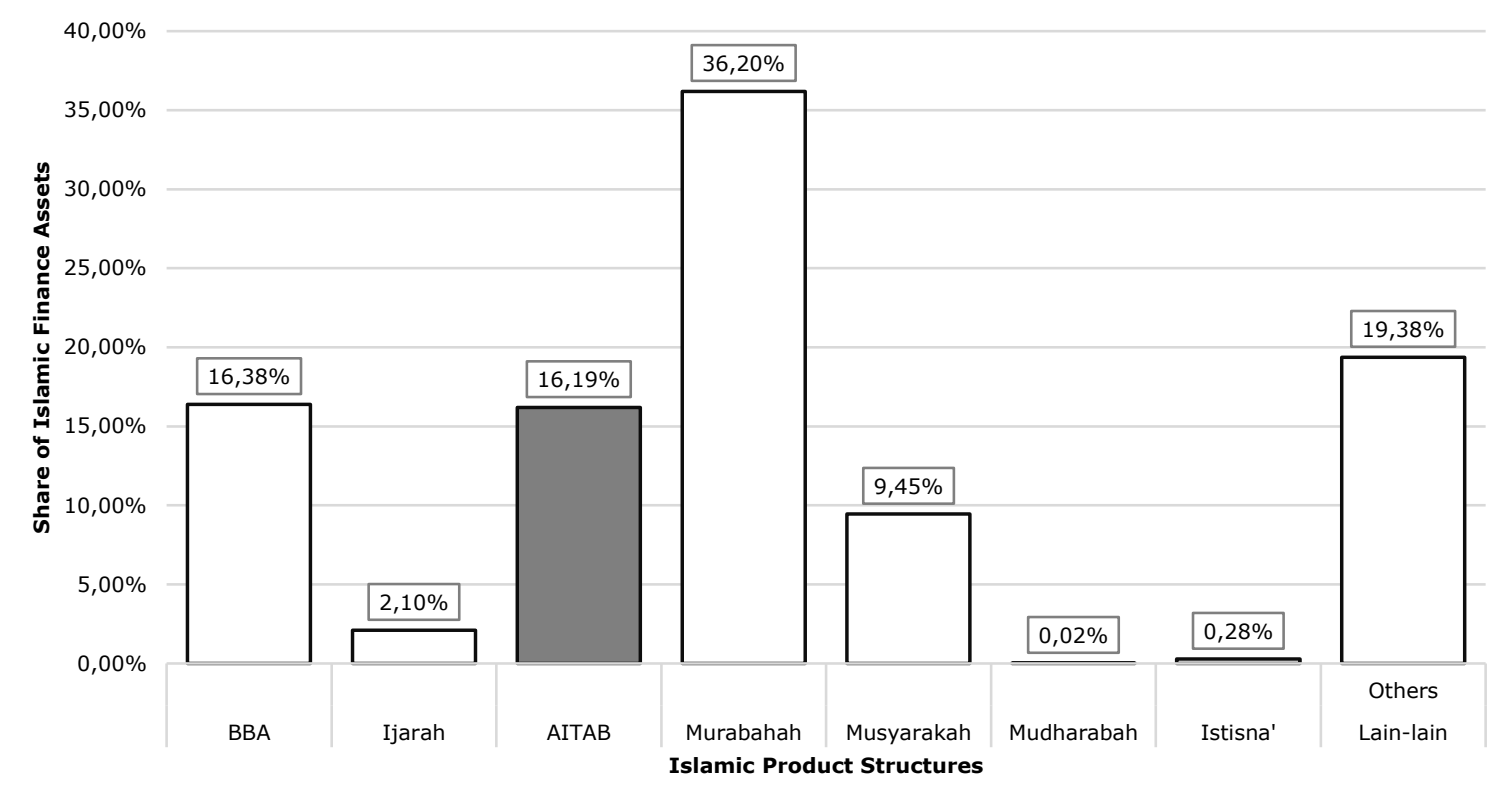

Bank Negara Malaysia (2016). Monthly Statistical Bulletin (2016): Islamic Banking System: Financing by Concept. Kuala Lumpur: Bank Negara.

\section{Figure 1: Islamic Finance by Concept in Malaysia 2016}

Further, the share of $A I T A B$ products among all vehicle financing loans has risen from $34.73 \%$ in 2011 to $42.32 \%$ in 2016 (Figure 2), showing the significance of Islamic finance in the vehicle financing sector (Bank Negara Malaysia, 2016)

The growth of AITAB happened in conjunction with an overall development of Islamic finance in Malaysia. Today, Thomson Reuters Zawya (2017) views Malaysia as the most developed Islamic finance market, ranking first in the 'Zawya Islamic Finance Development Indicator', as well as in the 'State of the Global Islamic Economy Report 2016' by Thomson Reuters (2016). Additionally, it is projected by the PEW Research Forum (2015) that the Muslim population in Malaysia will grow from 18.1 million (Share: 63.7\%) to 26.1 million in 2030 (68.1\%), wherefore Islamic finance will continue to experience increasing demand, generating the need for a deeper academic understanding of the field.

$56 \mid \begin{aligned} & \text { Marble } \\ & \text { Research } \\ & \text { Papers }\end{aligned}$ 


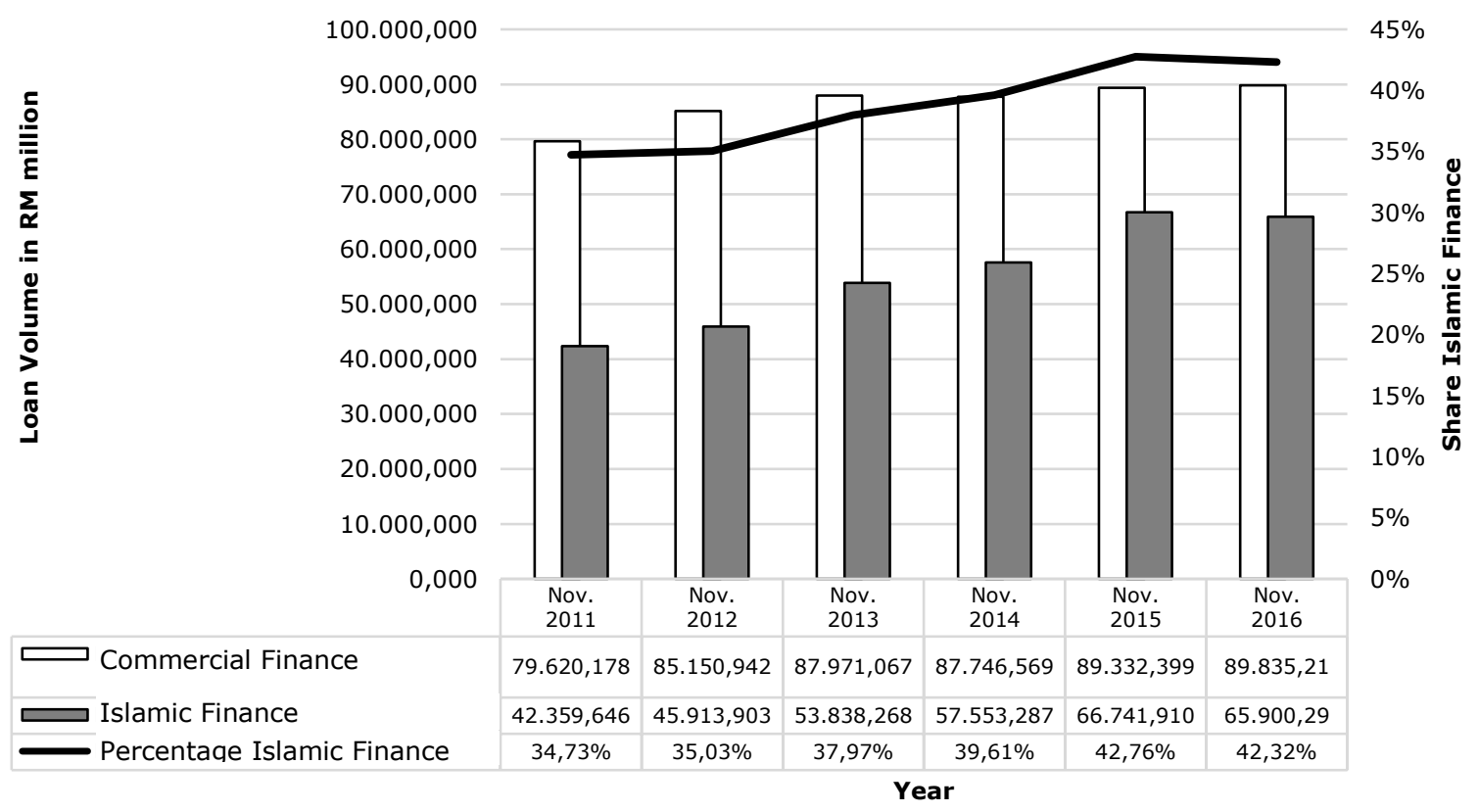

Bank Negara Malaysia (2016). Monthly Statistical Bulletin (2016): Banking Sytem: Loans Approved by Sector. Kuala Lumpur: Bank Negara.

Figure 2: Loan Volume Vehicle Hire Purchase in Malaysia 2016 (in RM million)

\subsection{Islamic Bank Selection Factors}

Despite the developed environment in Malaysia, data and research are still lacking in the sector and companies struggle to design and price Islamic finance products that meet customer demands. Bley and Kuehn (2004) investigated the knowledge and perceptions of Islamic finance in the United Arab Emirates (UAE) and found that religious beliefs are of higher importance for the selection of Islamic finance than financial literacy. The conclusion that ignorance is widespread in Islamic finance is further supported by Kahf (2002), who states that even bank personnel is not fully equipped with the relevant knowledge. Despite the relative age of the academic work, this observation was reconfirmed to be still applicable in interviews with leading Shariah advisories in Malaysia (Ramli, Kachkar, 2017). The finding of the predominant role of religion as an Islamic finance selection criteria is also the main outcome of Al-Ajmi, Hussein and Al-Saleh's research (2009), concerning the patronization of Islamic banks over conventional banking institutions in Bahrain. The authors found that religious belief and social responsibility are the two main reasons for a bank selection, and the cost/benefit for the customer only residing as the third most important factor. This implies that customers might be willing to pay a premium for Islamic finance, but no inference for the significance of the premium can be drawn.

Omar (2012) proved that the relevance of religion and Shariah compliance as the primary selection criteria is applicable to Malaysia as well, with profitability again only being of second order. Implications are that a bank cannot be too relaxed with Shariah compliant operations and should make efforts to ensure the 
adherence to Muslim teachings. All aforementioned findings therefore stand in stark contrast with findings relevant for conventional banking in Malaysia, where accessibility, convenience and pricing stipulate the prominent selection factors (Saleh, Rosman, \& Nani, 2013).

Further, Gait and Worthington (2008) offer insights about the attitudes of the individual consumer, the business side and financial institutions towards Islamic finance, conducted by the means of a comparative literature review. Most Malaysians do not differentiate between Islamic and conventional banking, despite high public awareness in comparison to other countries. This implies that knowledge of Islamic finance should not have an influence on the demand, and thus not on the price sensitivity. Moreover, it was found that Islamic finance users were older than 30 years, were often married and of higher income classes. Again, religious adherence and values worked as an explanatory variables to explain favorable perceptions towards Islamic finance offerings, being more important than pricing.

Loo (2010) expanded the scope of research, when not just investigating Muslim customers in Malaysia, but also including Non-Muslims in the research. Ethnic Chinese and Indians form the backbone of the Malaysian economy and therefore are of significance to corporations offering Islamic finance as well. He confirmed that the most attractive factor drawing customers towards Islamic banking is religion and observed that Muslims are more willing to engage with Islamic banks, while the most important factor for non-Muslims is product and service. Additionally, Muslims possess deeper knowledge of Islamic finance, wherefore a correlation of knowledge and the demand of Islamic finance is expected. In contrast to Gait and Worthington (2008), who found a positive relationship between demand for Islamic finance and age, Loo found a negative relationship with the higher demand stemming from the generation $Y$, aged younger than 30 years.

Additionally, according to Yildiz, Yildiz and Topal (2014), the influence of the environment of financing customers is not to be underestimated. Relationship and trust are values of utmost importance in the Islamic culture and the authors found, among various other selection criteria that the expectation of relatives and friends is of significance to the selection of an Islamic financing institution. No investigation about price sensitivity was offered, but it is reasonable to assume that social influence can probe a significant effect on the willingness to pay as well.

However, in the reviewed studies specifications about concrete Islamic finance product structures are limited and none of the investigated papers was exclusively dealing with an AITAB offering in the Malaysian vehicle financing market. Thus, Abdullah and Dusuki (2006) investigated the customers' perceptions of $A I T A B$ in Malaysia and found that customers are not fully aware of the difference between AITAB and conventional loans. Linking to the findings of Bley and Kuehn (2004), ignorance among customers prevails and staff often is not equipped with the relevant knowledge to explain the concept of AITAB in a proper manner.

The most relevant research for this thesis was conducted by Yusoff, Kamdari and Masri (2013) in a research series investigating the selection factors for AITAB in two different cities in Malaysia. The research was firstly conducted in the city of Shah Alam, and consecutively replicated in Kota Bharu by Yusoff and Kamdari (2014), whereby two cities of different economic advancement were captured. Findings concerning the selection factors in the developed city of Shah Alam show that the relationship between religious obligation and the acceptance of $A I T A B$ is positively significant. Further, a significant positive impact of awareness on the acceptance of $A I T A B$ was found and a significant positive relationship between social influence and $A I T A B$ recognized, reconfirming the findings of Yildiz, Yildiz and Topal (2014) for the Malaysian context. Those findings were also observed in Malaysia's less developed part (Kota Bharu), where again a significant influence of religious obligation, awareness and social influence was recognized.

$58 \mid$\begin{tabular}{l|l} 
Marble \\
Research
\end{tabular}

Papers 


\section{Hypotheses}

The reviewed literature lays the foundation for the hypotheses to assess the price sensitivity towards AITAB in Malaysia, justified by Berg, El-Komi and Kim's (2016) observation that a pricing premium can be charged arising from various degrees of Shariah conformity. Bley and Kuehn (2004), Gait and Worthington (2008), Loo (2010), Omar (2012) as well as Yusoff, Kamdiri and Masri (2013) all confirmed religion as well as religious obligation as the pivotal selection criteria for Islamic banks. Thus, it is to be expected that the adherence to Islam and the religious values of an individual will have the largest influence on the price sensitivity. Consequently, the following two hypotheses are derived:

$H_{1}$ : The price sensitivity of AITAB in Malaysia will be higher for Non-Muslims than for Muslims.

$\mathrm{H}_{2}$ : The price sensitivity of AITAB in Malaysia will be higher for individuals with liberal religious values than for individuals with conservative religious values.

The influence of knowledge on the demand of Islamic finance is inconclusive as Bley and Kuehn (2004) and Gait and Worthington (2008) recognized widespread ignorance in the field, whereas Loo (2010) and Yusoff, Kamdiri and Masri (2013) found a significant relationship between knowledge and demand. As the latter research was conducted in Malaysia and concerns the acceptance of AITAB directly, the following hypotheses are stated:

$H_{3}$ : The price sensitivity of AITAB in Malaysia will be lower for individuals with knowledge about Islamic finance in general.

$\mathrm{H}_{4}$ : The price sensitivity of AITAB in Malaysia will be lower for individuals with awareness about the AITAB offering.

Since Yusoff, Kamdari and Masri (2013), as well as Yildiz, Yildiz and Topal (2014) realized social influence as a selection criteria for Islamic finance, it is reasonable to investigate the impact of this factor on the price sensitivity as well. Thus, the following additional hypothesis is stated:

$H_{5}$ : The price sensitivity of AITAB in Malaysia will be lower for individuals who experience a larger social influence towards the use of Islamic finance.

Finally, demographic indications are inconclusive, with Gait and Worthington (2008) stating the strongest preference for Islamic finance is recognized within the age group older than 30, whereas Loo (2010) observed the opposite. As the research by Loo is elaborated in the Malaysian context, his findings are relatively stronger than the findings of Gait and Worthington and therefore hypothesized to hold true for the price sensitivity as well. Nonetheless, the indications from Gait and Worthington for the remaining demographic factors are still followed, suggesting that the price sensitivity is higher for singles, for low income and for academics. Thus, to investigate the effect of demographics on the price sensitivity, following hypotheses are formulated:

$H_{6}$ : The price sensitivity of AITAB in Malaysia is higher for individuals aged under 30 years.

H7: The price sensitivity of AITAB in Malaysia is higher for individuals in a lower income groups.

The Islamic Vehicle Financing Market in Malaysia: Identification of Factors Influencing Price Sensitivity 
Hs: The price sensitivity of AITAB in Malaysia is higher among Singles than other marital statuses.

$\mathrm{H}_{9}$ : The price sensitivity of AITAB in Malaysia is higher among individuals with a Bachelor degree or higher.

Arising from the aforementioned hypotheses, a multiple regression model to explain the price sensitivity of AITAB in Malaysia (YPS) is suggested as following:

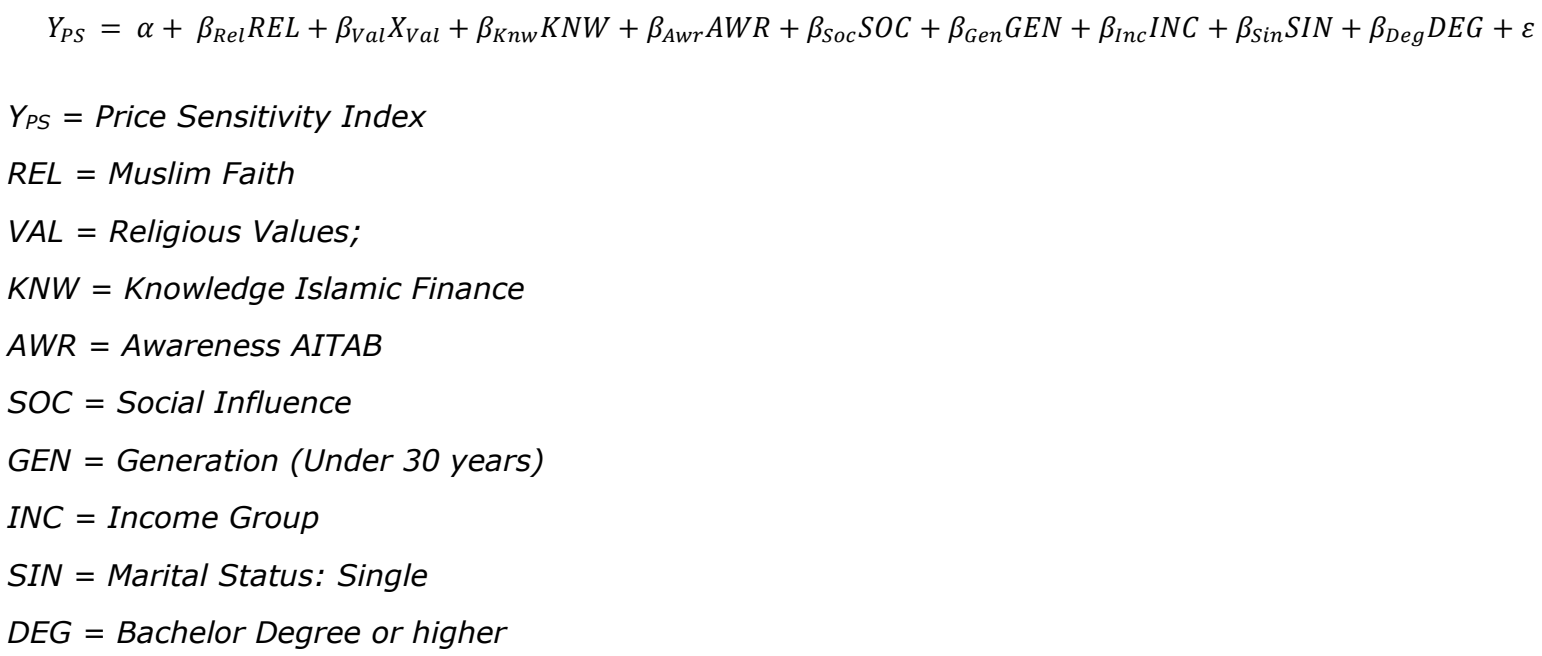

\section{Methodology}

\subsection{Survey Design}

A multiple regression was selected as the mean to assess the - from literature derived - influencing factors on price sensitivity in the Islamic vehicle finance market and as the study expands research beyond findings about bank selection factors, the methodology cannot be replicated from existing research. A severe limitation of previous studies, foremost of Yusoff, Kamdari and Masri (2013), was the estimation of demand by respondents based on an abstract 1-5 scale in a survey. This approach carries a demand characteristics response bias, with a research design being detached from any real offering, which in turn is not suitable for the monetization of consumer choices.

Therefore, this study is utilizing an experimental survey to collect data for the regression that allows recipients to obtain a more realistic picture of the AITAB product (Appendix A). The survey incorporated an experiment upfront, where respondents were asked to choose between two different financing contracts. The comparison was conducted four times, with the two opposing contracts always representing one AITAB contract and one conventional 'Hire Purchase' contract, however at changing price levels. The interest and profit rates that were displayed in the survey are summarized in table 1.

Table 1: Financing Contract Pairs in Survey

\begin{tabular}{lcc}
\hline & AITAB (Islamic finance) & Conventional Finance \\
\hline Q1: Equally Priced & $2.90 \%$ & $2.90 \%$ \\
Q2: Minor Price Difference & $2.95 \%$ & $2.90 \%$ \\
Q3: Medium Price Difference & $3.15 \%$ & $2.90 \%$ \\
Q4: Major Price Difference & $3.50 \%$ & $2.90 \%$ \\
\hline
\end{tabular}


During the experiment the respondent was given the option to indicate his demand on a 1-5 scale, where 1 indicated strongest demand for $A I T A B$ and 7 indicated the strongest demand for the conventional loan offering. The number 4 constituted being 'Indifferent'. The display of the offerings was designed in partnership with a local vehicle financing company in Malaysia to enable the most realistic comparison and included fields such as 'Loan Type', 'Description', 'Upfront Down payment', 'Amount to Finance', 'Tenure', 'Interest/Profit rate', and finally and most visible 'Monthly Instalment Payable'.

After the respondent indicated the respective preferences, he was asked regarding his personal knowledge about the general concept of Islamic finance, indicated on a 0-6 scale ranging from 'Strongly Disagree' to 'Strongly Agree'. To mitigate the risk of overconfidence bias, no question directly addressing the knowledge of Islamic finance was posed, but four questions of variating importance concerning concepts of Islamic finance. The statements that were posed to the recipients of the survey are listed in table 2.

Table 2: Components of 'Knowledge Islamic Finance' Variable

\begin{tabular}{lc}
\hline \multicolumn{1}{c}{ Question } & Weight \\
\hline I know that the Shariah should govern the everyday life of Muslims & $15 \%$ \\
I am familiar with general concepts of Islamic finance & $25 \%$ \\
I know that charging interest is forbidden in Islamic finance & $30 \%$ \\
I know that uncertainty is forbidden in Islamic transactions & $30 \%$ \\
\hline
\end{tabular}

The lowest weight was assigned to the first question, as it is concerned with knowledge about Islam in general. The last two questions were assigned with the highest weight due to the fact that both target the most essential concepts of Islamic finance and knowledge about these statements gives a sound indication about Islamic finance in general.

Afterwards, a question regarding the awareness of AITAB was posed directly, before the social influence was tested with a direct statement as well. The awareness was tested by means of a 'Yes/No' question, whereas the social influence was tested on a 0-6 scale.

The final part of the survey was concerned with the overall demographics that are to be found in hypotheses $\mathrm{H}_{1}$ and $\mathrm{H}_{2}$, as well as in $\mathrm{H}_{6}-\mathrm{H}_{9}$. The respondents were asked to indicate their religion and to estimate their religious values on a 1-7 scale, ranging from 'Very Conservative' to 'Very Liberal'. Finally, details about income, age, education and marital status were collected on a voluntary basis.

In order to set the collected results into perspective, proceedings from four individually conducted interviews were utilized. Razli Ramli, the Head Advisor from the Malaysian Shariah consultancy 'Islamic Banking \& Finance Institute Malaysia', as well as Dr. Omar Kachkar from the 'International Shariah Research Academy' were interviewed to rectify the correctness from a Shariah perspective. Furthermore, Tobias Eismann, the Chief Executive Officer of BMW Credit Malaysia was interviewed to discuss the implications for the Malaysian vehicle financing industry and Imad Omar Hafez, the Chief Operating Officer of BMW Finance Limited Middle East, was consulted to discuss the findings on a global level.

\subsection{Distribution of Survey}

The study is solely concerned with results collected in Malaysia, wherefore responses collected from other countries were disregarded. Before the survey was distributed to the general public, it was pilot-tested, 
involving ten respondents (Five local volunteers from Malaysia and five individuals from Maastricht University), who were excluded afterwards from the population. The survey was distributed in an online format, utilizing different channels. Firstly, it was distributed via Facebook to enable coverage in all parts of Malaysia within the age group younger than 30 years. To reach the generation older than 30 years, the survey was distributed by the academic institution 'Universiti Malaysia Kelantan' among its lecturers and affiliated associates in other parts of the less developed North-Malaysia. To gain coverage in the economically developed states of Kuala Lumpur, Negeri Sembilan, Melaka, Johor and Selangor, the survey was handed out to the personnel of all branches of the vehicle financer BMW Credit Sdn Bhd, and subsequently shared by its employees within their personal network.

\subsection{Adjustment of Data}

After responses were collected, a scale was developed measuring the price sensitivity for AITAB offerings:

$$
Y_{P S}=100-\left(\left(\frac{\left(8-d I F_{\text {MajorDiff }}\right)-1}{\left(8-d I F_{\text {NoDiff }}\right)}\right) \times 125\right)
$$

The rationale behind the price sensitivity index $Y_{P S}$ is that a ratio between the demand for Islamic finance at the major price difference (dIF MajorDiff $_{\text {) }}$ and the demand for Islamic finance at equal prices ( dIF $_{\text {NoDiff }}$ ) is measured. Both demand-estimates are subtracted from 8 to assign the largest number to the highest demand of Islamic finance. Next, the demand at major difference is adjusted by -1 to set the index equal to zero when demand is indicated at the lowest value (1). Subsequently, the ratio was multiplied by 125 to change the scale from 0-0.8 to 0-100 for an ease the understanding. Hence, the index indicates the likelihood that a customer switches from $A I T A B$ to a conventional loan when $A I T A B$ is priced more expensively. Due to the little value-add and to keep the formula for the price sensitivity index simple, the cases at minor price-difference and medium price-difference were disregarded.

Furthermore, to arise at the single variable 'Knowledge Islamic Finance', the four existing components were combined into one variable. Despite the low Cronbach's Alpha of 0.638 , measuring the relation of the components, a combination was viable because the four sub-questions were designed in a way that they do not require a similar response for each question. Next, the dummy variable 'Muslim Faith' was created and the dummy variable 'Age' established to differentiate respondents above 30 and below 30 years. The dummy variable 'Single' was incorporated to indicate whether a person in single or married/divorced and the income variable was compiled into eight different income groups. Finally, the four responses given for 'Education' were grouped into the variable 'Degree', which indicates whether an individual has obtained a Bachelor degree at minimum or not.

\section{Results}

\subsection{Frequency Distributions}

In total 146 surveys that were deemed relevant were returned and the analyzed sample shows a high quality, with nearly all questions answered by every respondent and only income group being characterized with 16 missing values. A summary of all frequencies and descriptive statistics of the variables is displayed in table 3.

\footnotetext{
$62 \mid \begin{aligned} & \text { Marble } \\ & \text { Research } \\ & \text { Papers }\end{aligned}$ 
Table 3: Descriptive Statistics

\begin{tabular}{|c|c|c|c|c|c|}
\hline Category & Answer & Count & Percent & Mean & Std. Dev. \\
\hline \multirow[t]{2}{*}{ Muslim Faith } & Muslim & 104 & $71.2 \%$ & & \\
\hline & Non-Muslim & 42 & $28.8 \%$ & & \\
\hline \multirow{7}{*}{ Religious Value } & Very Conservative & 4 & $2.7 \%$ & \multirow{7}{*}{3.93} & \multirow{7}{*}{1.44} \\
\hline & Conservative & 24 & $16.4 \%$ & & \\
\hline & Rather Conservative & 22 & $15.1 \%$ & & \\
\hline & Moderate & 55 & $37.7 \%$ & & \\
\hline & Rather Liberal & 16 & $11.0 \%$ & & \\
\hline & Liberal & 19 & $13.0 \%$ & & \\
\hline & Very Liberal & 6 & $4.1 \%$ & & \\
\hline \multirow{3}{*}{ Knowledge } & $0.00-2.00$ & 38 & $26.0 \%$ & & \\
\hline & $2.05-4.00$ & 45 & $30.8 \%$ & & \\
\hline & $4.05-6.00$ & 63 & $43.2 \%$ & & \\
\hline \multirow{2}{*}{ Awareness AITAB } & Yes & 85 & $58.2 \%$ & & \\
\hline & No & 61 & $41.8 \%$ & & \\
\hline \multirow{7}{*}{ Social Influence } & Strongly Disagree & 17 & $11.6 \%$ & \multirow{7}{*}{3.41} & \multirow{7}{*}{2.05} \\
\hline & Disagree & 17 & $11.6 \%$ & & \\
\hline & Somewhat Disagree & 18 & $12.3 \%$ & & \\
\hline & Neither Agree / Disagree & 17 & $11.6 \%$ & & \\
\hline & Somewhat Agree & 22 & $15.1 \%$ & & \\
\hline & Agree & 24 & $16.4 \%$ & & \\
\hline & Strongly Agree & 31 & $21.2 \%$ & & \\
\hline \multirow{2}{*}{ Single } & Single & 75 & $51.4 \%$ & & \\
\hline & Other & 71 & $48.6 \%$ & & \\
\hline \multirow[t]{2}{*}{ Degree } & STPM/Diploma or lower & 25 & $17.1 \%$ & & \\
\hline & Bachelor or higher & 121 & $82.9 \%$ & & \\
\hline \multirow[t]{2}{*}{ Generation } & $<30$ Years & 70 & $47.9 \%$ & & \\
\hline & $>=30$ Years & 76 & $52.1 \%$ & & \\
\hline \multirow{8}{*}{ Income Group } & No Income & 19 & $13.0 \%$ & \multirow{8}{*}{2.17} & \multirow{8}{*}{1.52} \\
\hline & $1-2,500 \mathrm{RM}$ & 23 & $15.8 \%$ & & \\
\hline & $2,500-5,000 \mathrm{RM}$ & 44 & $30.1 \%$ & & \\
\hline & $5,001-7,500 \mathrm{RM}$ & 21 & $14.4 \%$ & & \\
\hline & $7,501-10,000$ RM & 11 & $7.5 \%$ & & \\
\hline & $10,001-15,000 \mathrm{RM}$ & 9 & $6.2 \%$ & & \\
\hline & $15,001-20,000$ RM & 2 & $1.4 \%$ & & \\
\hline & $>20,000 \mathrm{RM}$ & 1 & $0.7 \%$ & & \\
\hline
\end{tabular}

The Islamic Vehicle Financing Market in Malaysia: Identification of Factors Influencing Price Sensitivity 
The majority of respondents were of Muslim faith $(71.2 \%)$, which is in line with the composition of Malaysia's overall ethnic population composition. Among all respondents, it is observable that the variable 'Religious Value' is normally distributed, thus fitting for the regression with the median at the moderate religious value. Furthermore, 75 respondents indicated to be single, whereas 71 indicated to be either married, divorced or widowed. Similar, for the variable 'Generation' 70 respondents indicated to be younger than 30 years and 76 indicated to be older or equal to 30 years. The majority of the sample was of higher educational background, with $82.9 \%$ having achieved a Bachelor degree at minimum. This is of high importance to the reliability of the data because financial literacy is required to fully understand the two different financial loan offerings that were displayed in the survey. Lastly, the variable 'Income Group' is slightly skewed to the right, implying that the majority of respondents are earning less than 7,500 Ringgit (RM) per month.

As the price sensitivity index was only constructed from the two cases at both extremes of the range, only the cases at equal price and with a major price difference of $0.6 \%$ in interest rate are of interest for the results. When the results are transformed into the price sensitivity index, a moderate overall mean score of 55.35/100 with a high standard deviation of 41.61 is recognized.

Finally, conflicting responses about Islamic finance knowledge in Malaysia were given, as the scope of knowledge differs between the four sub-questions in the 'Knowledge Islamic Finance'. This implies that when an individual possesses some knowledge about Islamic finance, it does not mean that the topic is understood as a whole. Additionally, the expected overconfidence becomes observable as knowledge is assessed higher in the generic question about Islamic finance (Q2) than about concepts that are vital to the full understanding of Islamic finance (Q3/Q4). Finally, when all four components are combined into the one variable, a mean of 3.39 indicates only moderate knowledge and a standard deviation of 1.70 implies that knowledge varies largely within the population.

The awareness about the AITAB product yields in a significant differential in the population as well, but with the majority possessing at least some knowledge about the concept. The outcome for the assessment of the social influence towards Islamic finance is characterized by a flat distribution that states the large variation of social influence in the sample.

\subsection{Testing of the Hypotheses}

Generally, no strong non-linearities are observable for all variables, only slight non-linearities are existent for the variables 'Muslim Faith', 'Religious Values', and 'Generation' with the scatter of the residuals not appearing in a complete random matter. Further, independence is provided by the distribution of the survey to separate individuals, spread over the country and independent of each other. The Equal Variance condition is also confirmed to be true, as an equal variance is recognized across all explanatory variables, only for 'Social Influence' a slight fanning out of the residuals is recognized and the normal distribution of residuals is confirmed in the proposed model. As no violations of assumptions are noticeable, a multiple linear regression was used to estimate the price sensitivity towards Islamic vehicle financing. The results showed a collective significant effect between the variables 'Muslim Faith', 'Religious Values', 'Knowledge Islamic Finance', 'Awareness AITAB', 'Social Influence', 'Generation', 'Income Group', 'Single' and 'Degree' $\left(F(9,129)=17.766, \mathrm{p}<.001, \mathrm{R}^{2}=.571\right)$.

Hence, the $R^{2}$ of 0.57 , states that only $57 \%$ of the variance in the sample can be explained by the model. Considering that research about Islamic finance is still in its infancy stage, a low value is of little surprise and future research has yet to reveal more insights about consumer behavior in the field of Islamic finance.

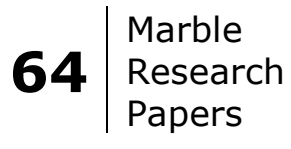


Nonetheless, the value is high enough to claim that the model includes the majority of factors that are of influence to the price sensitivity in the Islamic vehicle financing market. It is noteworthy that the model shows an adjusted $R^{2}$ of only 0.54 , which deviates from the $R^{2}$ by 0.03 and thus may indicate redundancy of variables in the model. Despite the relatively small $R^{2}$ of 0.57 , the suggested model shows statistical significance with $F(9,129)=17.77$ and $p<0.001$. Hence, the model is assumed to be fitting before further adjustments and reductions of variables are considered.

The results of the individual variables are shown in table 4. All variables show a Variance Inflation Factor (VIF) of 1.093-2.041, stating if explanatory variables are strongly linear related to each other. According to Kerkhoffs (2016), all can be claimed to be of little or no collinearity due to a value noticeably below 10 , hence standard errors are true and insignificant variables truly irrelevant.

Table 4: Multiple regression on price sensitivity

\begin{tabular}{|c|c|c|c|c|c|}
\hline Model & $t$ & $p$ & $\beta$ & Std. Error & VIF \\
\hline Constant & 0.35 & 0.727 & 5.567 & 15.904 & \\
\hline Muslim Faith & -3.556 & 0.001 & -23.877 & 6.715 & 1.37 \\
\hline Religious Values & 7.883 & 0 & 15.043 & 1.908 & 1.246 \\
\hline Knowledge Islamic Finance & 2.329 & 0.022 & 3.905 & 1.677 & 1.292 \\
\hline Awareness AITAB & -2.993 & 0.003 & -16.56 & 5.533 & 1.199 \\
\hline Social Influence & -0.396 & 0.693 & -0.543 & 1.373 & 1.292 \\
\hline Generation & -0.521 & 0.603 & -3.621 & 6.949 & 1.929 \\
\hline Income Group & 0.616 & 0.539 & 1.451 & 2.355 & 2.041 \\
\hline Single & 1.717 & 0.089 & 10.464 & 6.095 & 1.49 \\
\hline Degree & -0.341 & 0.733 & -2.296 & 6.727 & 1.093 \\
\hline
\end{tabular}

The dummy variable 'Muslim Faith' shows high significance with a P-value of 0.001 and a beta of 23.877, meaning if an individual is of Muslim faith, all else equal, its price sensitivity to the AITAB product will be significantly lower by 23.877 points and he is less likely to switch when Islamic finance is pricier. This finding is of no surprise and fails to reject the $\mathrm{H}_{1}$, showing that Muslims show lower price sensitivity than Non-Muslims.

Furthermore, the $\mathrm{H}_{2}$ is also accepted, as the variable 'Religious Values' shows a positive beta of 15.043, significant with a P-Value of below 0.001 . This implies that the price sensitivity increases by 15.043 for every step on the scale from 'Very Conservative' to 'Very Liberal'. Hence, more liberal individuals are characterized by higher price sensitivity and thus are more inclined to switch to conventional finance offerings when Islamic finance is priced higher.

The variable 'Knowledge Islamic Finance' is also significant at the $5 \%$ significance level, contributing interesting insights as research about the influence of knowledge on demand had been inconclusive in the past. The positive beta of 3.905 indicates that the more knowledge about the subject is in place, the more concerns about pricing arise. This finding rejects the $\mathrm{H}_{3}$ but is in line with the research by Bley and Kuehn (2004), Kahf (2002) and interviews with Ramli (2017) and Kachkar (2017), who line out large ignorance prevailing in the field. But not just the knowledge about Islamic finance itself is influential, also the influence of 'Awareness $A I T A B$ ' itself is significant. If respondents knew the product structure prior to the 
survey, they were 16.560 points less price sensitive than if no awareness would be prevailing, significant at the $5 \%$ significance level. Hence, $\mathrm{H}_{4}$ is accepted, which stands in contrast to the rejection of $\mathrm{H}_{3}$ that confirmed that ignorance decreases the price sensitivity. The result appears counterintuitive, but a rationale behind this finding might be that the Muslim population is equipped with higher awareness levels for Islamic finance products and thus it should influenced by the variable 'Muslim Faith'. The claim is supported by a two-sample t-test with equal variances assumed, that compares the respective means of 'Awareness $A I T A B$ ', grouped by 'Muslim Faith'. The results indicate that there is indeed a significant difference in the awareness of the AITAB product between Muslims and Non-Muslims $(\mathrm{t}(144)=2.856, \mathrm{p}<$ 0.001 ), wherefore it can be assumed that 'Awareness $A I T A B^{\prime}$ is partially driven by 'Muslim Faith'. However, when taking the low VIF of 1.189 for 'Awareness $A I T A B^{\prime}$ into account, no concern for collinearity is apparent.

The inclusion of the 'Social Influence' variable was hypothesized to be negative, with social pressure decreasing price sensitivity. However, as the variable is highly insignificant with a P-Value of 0.693 no interpretation of the beta is reliable.

Finally, most of the demographic factors have little power in explaining the price sensitivity as well, with 'Generation', 'Income Group' and 'Degree' all being highly insignificant and therefore also not of added value for the model. Only the variable 'Single' is worth further investigation, due to its significance at the $10 \%$ level, but insignificance at $5 \%$. The beta is loaded positively with a factor of 10.464 , stating that Singles are 10.464 points more price sensitive than individuals of any other marital status.

Due to various insignificant variables and the lower adjusted $\mathrm{R}^{2}$, it was seen worthy to reinstate the model with fewer variables. The following model was suggested for a better fit and a regression, and a partial Ftest were conducted to test the added value of the reduced model:

$$
Y_{P S}=\alpha+\beta_{R e l} R E L+\beta_{V a l} V A L+\beta_{K n w} K N W+\beta_{A w r} A W R+\beta_{S i n} S I N+\varepsilon
$$

$Y_{P S}=$ Price Sensitivity Index

REL = Muslim Faith

$V A L=$ Religious Values

$K N W=$ Knowledge Islamic Finance

$A W R=$ Awareness AITAB

SIN = Marital Status: Single

The results of the revised model showed again a collective significant effect between the variables 'Muslim Faith', 'Religious Values', 'Knowledge Islamic Finance', 'Awareness AITAB' and 'Single' $(F(4,145)=42.99$, $\left.p<.001, R^{2}=.549\right)$. However, the partial F-test unveils that the simpler model is not better suited, since the F-statistic of 3.11 cannot be rejected at the $5 \%$ significance level:

$$
F=\frac{\left(S S E_{r}-S S E_{c}\right) /(k-g)}{S S E_{c} /(n-k)}=\frac{(113094.91-97235.06) /(9-4)}{97235.06 /(145-9)}=3.11
$$

\footnotetext{
$66 \mid$\begin{tabular}{l|l} 
Marble \\
Research
\end{tabular} 
Thus, the claim that all factors influencing price sensitivity are the equal is rejected and 'Muslim Faith', 'Religious Values', 'Awareness $A I T A B^{\prime}$ and 'Single' are not the only important driving factors. Hence, the larger model is more suitable to explain price sensitivity in the Islamic vehicle finance market and the interpretation of variables in the reduced model is not further elaborated.

\section{Discussion}

The presented findings enable a deeper understanding of customer behavior in the Islamic vehicle finance sector and can help corporations with their internal pricing decisions when introducing an $A I T A B$ product into their portfolio. The acceptance of $\mathrm{H}_{1}$, implying that Non-Muslims are significantly more sensitive to changes in pricing for Islamic finance, shows that corporations need to carefully price their products when segmenting customer groups based on religion. The finding implies a price insensitivity of the Muslim population, wherefore higher prices are be acceptable for this group. However, if a pricing differential between Islamic and conventional finance is introduced by any corporation, Non-Muslim customers are likely to be excluded from the potential customer group, contrasting the view that Islamic finance should be viewed as finance for everyone.

The acceptance of $\mathrm{H}_{2}$ furthermore is of interest to various vehicle financers in Malaysia, as customer segments differ by brand. In Malaysia, premium manufacturers are often characterized by a more liberal customer group, whereas the national manufacturers Proton and Perodua have a large conservative customer base (Eismann, 2017). As the price sensitivity increases with more liberalism, it might be more realistic for corporations with a conservative base to charge a premium on AITAB, whereas Premium manufacturers should offer an equally priced product, considering the needs of the liberal consumers. Interestingly, this finding does not only hold for the Muslim part of the population, but for all religious groups within Malaysia.

The positive beta loading for the 'Knowledge Islamic Finance' variable follows up on the inconclusive research offered by previous research papers. This study confirms a positive, significant relationship between knowledge and the price sensitivity for an AITAB offering. Thus, corporations have to be very cautious if a premium is demanded to not suffer from a reputational loss among the knowledgeable customers, as the premium can appear as an unfair treatment of customers (Eismann, 2017). With increasing awareness and educational campaigns being launched in Malaysia by the Bank Negara, one can expect that the price sensitivity will increase in the future.

The negative relationship of 'Awareness $A I T A B^{\prime}$ ' with price sensitivity is partially driven by 'Muslim Faith', reasoned by the aforementioned two-sample t-test but also explained by the overall customer satisfaction of the financing product $A I T A B$. The research and consultancy firm J.D. Power (2017) investigated the Malaysian vehicle finance market and found that customers buying Islamic vehicle finance products are characterized by a higher overall satisfaction compared to customers buying conventional loans. It is likely that the higher willingness to pay for $A I T A B$ is caused by its more customer-friendly offering, wherefore corporation should emphasize education about the product structure.

The final significant variable 'Single' also confirms the proposed hypothesis $\mathrm{H}_{8}$ and thereby is in line with research conducted by Gait and Worthington (2008), however extended by taking different price levels into consideration. This research states that an individual with 'Single' as the marital status is more price sensitive than any other status. As it is the only demographic variable that is relatively significant, a justification for this finding based on income, age or generation is not possible. However, the significance of the variable can be explained by Booth, Johnson, Branaman and Sica (1995), who found that marital 
status improves religious happiness and increases the conformance to religion. The authors assumed that a married person changes its behavior resulting from the new role as a paragon when married. Thus, adherence to religion is valued more and the willingness to pay more for Shariah compliant products increases, mirrored in the lower price sensitivity.

All other variables that were proven significant as a selection factor for Islamic finance by related research are insignificant as a factor influencing the price-sensitivity in the Islamic vehicle financing market, therefore no interpretation is possible. Nonetheless, knowing that religion, religious values, awareness and marital status influences the customer's behavior at different pricing levels already offers very valuable insights for corporations investigating Islamic vehicle finance.

These findings unveil new aspects of customer behavior in Malaysia, however the findings are countryspecific. Reasoned by the unique ethnic population structure of Malaysia, combined with the most developed dual banking system worldwide, one cannot extrapolate the findings to other markets where Islamic finance plays a significant role. In dominant Islamic finance markets, like Saudi Arabia or the UAE, no comparable conventional alternative is given to customers, thus customers are often only left with the Shariah-compliant alternative (Hafez, 2017). In markets that only facilitate Islamic finance on a small scale, like the United Kingdom or South Africa, awareness and knowledge are lacking in the population, wherefore the variables selected in this study would not yield in the same outcomes (EY MENA, 2015). Further, laws are not in place to put Islamic finance on par to conventional finance. However, in this setting, it would be interesting to investigate in how far the price sensitivity differs to the findings presented in this study.

\section{Limitations}

Despite Malaysia's development, the topic of Islamic finance is not well-researched, wherefore only a limited number of relevant sources are available, especially from world-renowned journals. The availability of peer-reviewed papers is even further limited, consequently it is not unlikely that more Islamic banking selection factors exist, which also extrapolate into the price sensitivity of Islamic vehicle finance.

Furthermore, the survey design carries the limitation of being of theoretical nature, not investigating reallife cases. The survey is set up as an experiment that already mitigates limitations found in prior research, but a social desirability bias is still likely, understating the price sensitivity of the Muslim sub-group. As a mitigation of this bias, the results were collected on an anonymous basis to not create any social pressure. In addition, the survey was marked by a churn rate of more than $20 \%$ because a certain degree of financial literacy is required. Nonetheless, this fallacy should not be viewed as restricting, as the survey was thus filtered for respondents who are not capable of answering the financial questions.

The analysis of the data is the last limiting factor for a twofold reason. Firstly, the index for the measurement of price sensitivity is held relatively simply, assessing the ratio between the equal pricing and the larger price differential, and thereby enabling an artificial scale from $0-100$. This scale possesses the property of giving an indication about the general price sensitivity, however cannot mirror choices in exact monetary terms and also does not measure the willingness to pay at different price levels. Here, future research is suggested to measure sensitivity at various price-levels. A second limitation of the data analysis is the combination of the four different components concerning knowledge about Islamic finance into one 'Knowledge Islamic Finance' variable, which was conducted according to personal assessment but with a low Cronbach's Alpha. The decision to combine the variables is still reasonable, based on the rationale that not all components were meant to return the results on an equal scale.

$68 \mid \begin{aligned} & \text { Marble } \\ & \text { Research } \\ & \text { Papers }\end{aligned}$ 


\section{Conclusion}

Islamic finance is a highly relevant topic in Malaysia and the vehicle finance market is among the most developed segments, incorporating a business volume that makes the market entry attractive to several financing corporations. After several studies have been launched in the recent years about the selection factors in the Islamic banking, this study constitutes a first attempt of measuring the price sensitivity in this segment by customers. This will help corporations when customizing the product portfolio and will assist in the pricing decisions when entering the Islamic vehicle financing market.

It was found that several factors that are significant as a selection factor for Islamic finance also extend into price sensitivity. As Muslims and Non-Muslims are potential customers of Islamic finance, both groups were included in the study, however the possession of Muslim faith is deemed as a significant negative factor influencing the price sensitivity. Further, not just the belongingness to Islam is influential, but also the way of practicing any religion, with liberal individuals being of higher sensitivity. The knowledge about Islamic finance in general is also of influence, where respondents with less knowledge are willing to pay more, confirming the prevalence of ignorance in the sector.

Contrasting, awareness of the Islamic vehicle finance product AITAB is of negative influence, making people less sensitive if awareness about the structure exists, likely to be caused by Muslim faith and customer satisfaction. Finally, the marital status of being single also influences the willingness to pay of customers, with singles being more sensitive to price changes, as conformity to religion is less required. This research provides a good foundation about the price sensitivity, however should be expanded by more sophisticated methods in the future and more research is required to offer better rationales behind the findings. Nonetheless, this study shows that religion is not the only influencing factor, but also religious values, knowledge about Islamic finance, awareness about AITAB and the marital status single. This is of significant added value to corporations in the vehicle financing market, as new insights into consumer behaviors within the sector are delivered by this thesis. Based on specific customer groups, corporations entering the Islamic vehicle financing market now have a clearer idea whether a premium for an $A I T A B$ offering is justifiable.

\section{References}

Abdullah, N. I., \& Dr. Dusuki, A. W. (2014). A Critical Appraisal of Al-Ijarah Thumma al-Bai' (AITAB) operation: Issues and Prospects. 4th International Islamic Banking and Finance Conference ( $\mathrm{pp}$. 1-15). Kuala Lumpur: Monash University of Malaysia.

Abdullah, N. I., \& Dusuki, A. W. (2006). Customers' Perceptions of Islamic Hire-Purchase Facility in Malaysia: An Empirical Analysis. IIUM Journal of Economics and Management, 14(2), 177-204.

Al-Ajmi, J., Hussein, H., \& Al-Saleh, N. (2009). Clients of conventional and Islamic banks in Bahrain. International Journal of Social Economics, 36(11), 1086-1112.

Bank Islam Malaysia Berhad. (n.d.). Application of Shariah Contracts in Islamic Banking Products and Services. Kuala Lumpur: Bank Islam Malaysia Berhad.

Bank Negara Malaysia. (2014). Ijarah Concept Paper. Kuala Lumpur: Bank Negara Malaysia.

Bank Negara Malaysia. (2016, December 30). Monthly Statistical Bulletin Novemeber 2016. Kuala Lumpur, Kuala Lumpur, Malaysia.

Berg, N., El-Komi, M., \& Kim, J.-Y. (2016). Market segmentation and non-uniform Shariah standards in Islamic finance. Journal of Economic Behavior \& Organization, 132, 39-49.

Bley, J., \& Kuehn, K. (2004). Conventional versus Islamic Finance: Student Knowledge and Perception in the United Arab Emirates. International Journal of Islamic Financial Services, 5(4), 17-30.

Booth, A., Johnson, D. R., Branaman, A., \& Sica, A. (1995). Belief and Behavior: Does Religion Matter in Today's Marriage? Journal of Marriage and Family, 57(3), 661-671.

Eismann, T. (2017, May 25). CEO, BMW Credit (Malaysia) Sdn Bhd. (J. Werner, Interviewer)

The Islamic Vehicle Financing Market in Malaysia: Identification of Factors Influencing Price Sensitivity 
EY MENA. (2015). World Islamic Banking Competitivness Report 2014-15. Manama: EY MENA.

Gait, A., \& Worthington, A. (2008). An empirical survey of individual consumer, business firm and financial institudtion attitudes towards Islamic methods of finance. International Journal of Social Economics, 35(11), 783-808.

Hafez, I. O. (2017, April 3). COO BMW Finance Limited Middle East. (J. Werner, Interviewer)

International Monetary Fund. (2017, February). The IMF and Islamic Finance. Retrieved from imf.org: http://www.imf.org/external/themes/islamicfinance/

Iqbal, Z., \& Mirakhor, A. (2011). An Introduction to Islamic Finance. Singapore: John Wiley \& Sons (Asia) Pte. Ltd.

J.D.Power. (2017). 2017 Malaysia Auto Consumer Finance Study. Kuala Lumpur: J.D.Power.

Kachkar, O. (2017, April 12). Manager (International Shariah Research Academy). (J. Werner, Interviewer)

Kahf, M. (2002). Strategic Trends in the Islamic Banking and Finance Movement. Harvard Forum on Islamic Finance and Banking. Cambridge, Boston: Harvard University.

Kerkhoffs, C. (2016). Quantitative Methods 3 (EBS2001), 205/2016, lecture 2. QM Emerging Markets ( $p$. 31). Maastricht: Maastricht University.

Loo, M. (2010). Attitudes and Perceptions towards Islamic Banking among Muslims and Non-Muslims in Malaysia: Implications for Marketing to Baby Boomers and X-Generation. International Journal of Arts and Science, 3(13), 453-485.

Moghul, U. F. (2006). Introduction to Islamic Finance. Boston: Federal Reserve Bank of Boston.

PEW Research Forum. (2015, April 2). Religious Composition by Country, 2010-2050. Washington DC, Washington DC, United States.

Ramli, R. (2017, March 8). Head / Principal Advisor (Islamic Banking \& Finance Institute Malaysia). (J. Werner, Interviewer)

Saleh, M. S., Rosman, M. R., \& Nani, N. K. (2013). Bank Selection Criteria in a Customers' Perspective. IOSR Journal of Business and Management, 7(6), 15-20.

The Economist. (2015, September 25). Economic Malays. Retrieved from economist.com: http://www.economist.com/blogs/graphicdetail/2015/09/malaysia-graphics

Thomson Reuters. (2016). State of the Global Islamic Economy 2016/17. Dubai: Thomson Reuters .

Thomson Reuters Zawya. (2017, February 14). Islamic Finance Development Indicator (IFDI). Retrieved from zawya.com: http://www.zawya.com/islamic-finance-development-indicator/

Trading Economics. (2017, May 23). Malaysia Wages. Retrieved from tradingeconomics.com: http://www.tradingeconomics.com/malaysia/wages

Yildiz, S., Yildiz, E., \& Topal, M. H. (2014). Islamic marketing as a new marketing trend: an application for determining consumers' Islamic bank selection criteria. Banks and Bank Systems, 9(1), 2227.

Yusoff, R., \& Kamdari, N. A. (2014). Selection Factors of the Acceptance Al-Ijarah Tumma Al Bay (Aitab) in Kota Bharu, Kelantan. Malaysian Journal of Business and Economics, 1(2), 23-50.

Yusoff, R., Kamdari, N. A., \& Masri, D. N. (2013). Selection Factors of the Acceptance Al-Ijarah Thumma Al Bay (AITAB) in Shah Alam. 5th Islamic Economies System Conference (iECONS 2013) (pp. 302-325). Kuala Lumpur: Universiti Sains Islam Malaysia.

Zubairi, S. (2011). Shariah Structuring, Documentation \& Product Development. Shariah Coordination Department (pp. 1 - 252). Dubai: Dubai Islamic Bank. 


\section{Appendix}

Appendix A: Survey Design

I. Equally Priced Comparison

\begin{tabular}{|l|}
\hline Financier \\
\hline Loan Type \\
\hline Details \\
\hline Description \\
\hline Upfront downpayment \\
\hline Amount to Finance \\
\hline Tenure \\
\hline Interest/Profit Rate \\
\hline $\begin{array}{l}\text { Monthly Instalment } \\
\text { Payable }\end{array}$ \\
\hline
\end{tabular}
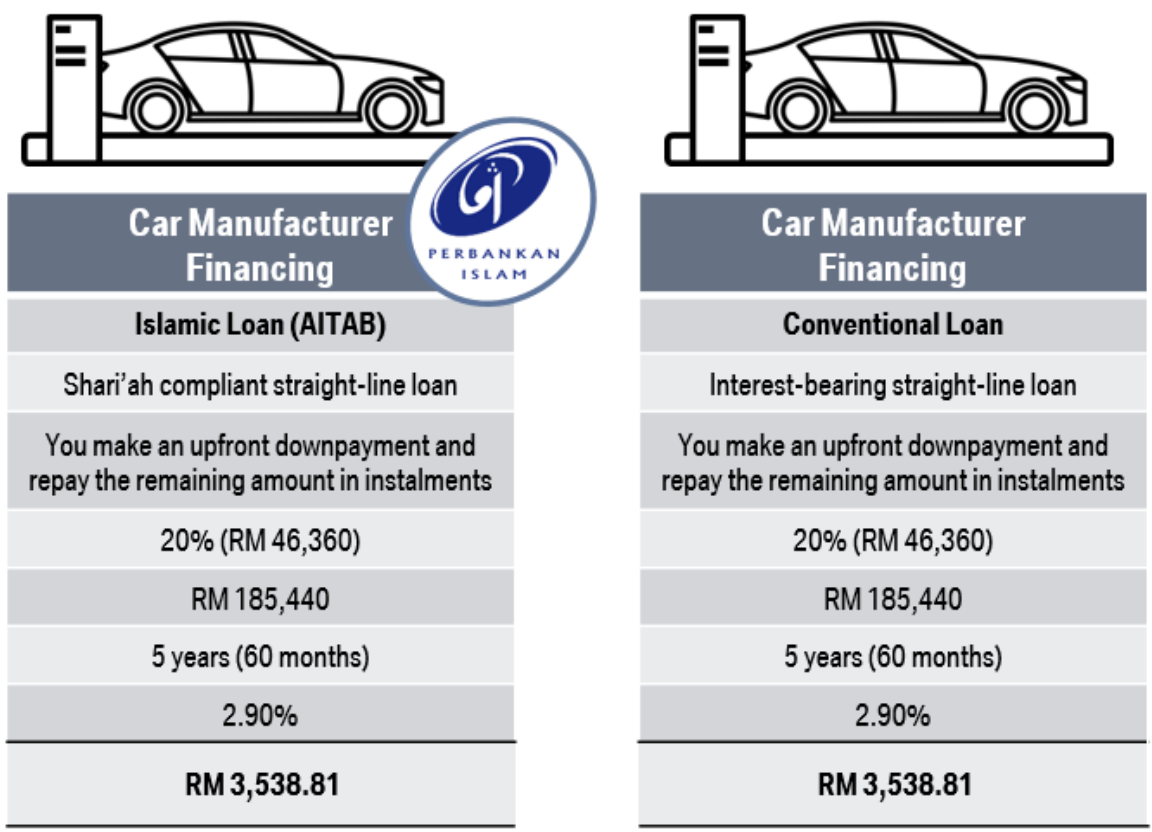

II. Minor Price Difference

\begin{tabular}{|c|c|c|}
\hline Financier & $\begin{array}{c}\text { Car Manufacturer } \\
\text { Financing }\end{array}$ & $\begin{array}{c}\text { Car Manufacturer } \\
\text { Financing }\end{array}$ \\
\hline Loan Type & Islamic Loan (AITAB) & Conventional Loan \\
\hline Details & Shari'ah compliant straight-line loan & Interest-bearing straight-line loan \\
\hline Description & $\begin{array}{l}\text { You make an upfront downpayment and } \\
\text { repay the remaining amount in instalments }\end{array}$ & $\begin{array}{l}\text { You make an upfront downpayment and } \\
\text { repay the remaining amount in instalments }\end{array}$ \\
\hline Upfront downpayment & $20 \%(\mathrm{RM} 46,360)$ & $20 \%$ (RM 46,360) \\
\hline Amount to Finance & RM 185,440 & RM 185,440 \\
\hline Tenure & 5 years ( 60 months) & 5 years ( 60 months) \\
\hline Interest/Profit Rate & $2.95 \%$ & $2.90 \%$ \\
\hline $\begin{array}{l}\text { Monthly Instalment } \\
\text { Payable }\end{array}$ & RM 3,546.54 & RM 3,538.81 \\
\hline
\end{tabular}

The Islamic Vehicle Financing Market in Malaysia: Identification of Factors Influencing Price Sensitivity 
III. Medium Price Difference

\begin{tabular}{|l|}
\hline Financier \\
\hline Loan Type \\
\hline Details \\
\hline Description \\
\hline Upfront downpayment \\
\hline Amount to Finance \\
\hline Tenure \\
\hline Interest/Profit Rate \\
\hline $\begin{array}{l}\text { Monthly Instalment } \\
\text { Payable }\end{array}$ \\
\hline
\end{tabular}
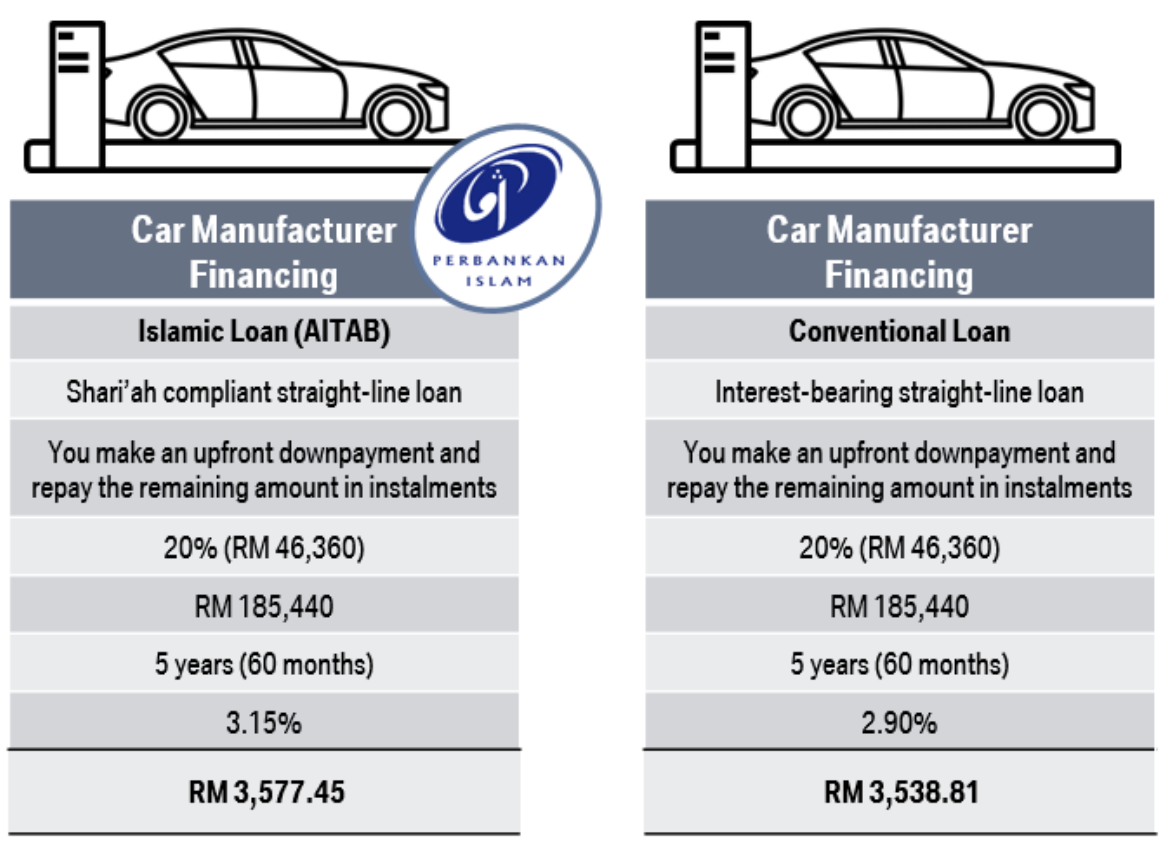

IV. Major Price Difference

\begin{tabular}{|c|c|c|}
\hline Financier & $\begin{array}{c}\text { Car Manufacturer } \\
\text { Financing }\end{array}$ & $\begin{array}{l}\text { Car Manufacturer } \\
\text { Financing }\end{array}$ \\
\hline Loan Type & Islamic Loan (AITAB) & Conventional Loan \\
\hline Details & Shari'ah compliant straight-line loan & Interest-bearing straight-line loan \\
\hline Description & $\begin{array}{l}\text { You make an upfront downpayment and } \\
\text { repay the remaining amount in instalments }\end{array}$ & $\begin{array}{l}\text { You make an upfront downpayment and } \\
\text { repay the remaining amount in instalments }\end{array}$ \\
\hline Upfront downpayment & $20 \%$ (RM 46,360) & $20 \%(\mathrm{RM} 46,360)$ \\
\hline Amount to Finance & RM 185,440 & RM 185,440 \\
\hline Tenure & 5 years (60 months) & 5 years ( 60 months) \\
\hline Interest/Profit Rate & $3.50 \%$ & $2.90 \%$ \\
\hline $\begin{array}{l}\text { Monthly Instalment } \\
\text { Payable }\end{array}$ & RM 3,631.53 & RM 3,538.81 \\
\hline
\end{tabular}

$72 \mid \begin{aligned} & \text { Marble } \\ & \text { Research } \\ & \text { Papers }\end{aligned}$ 